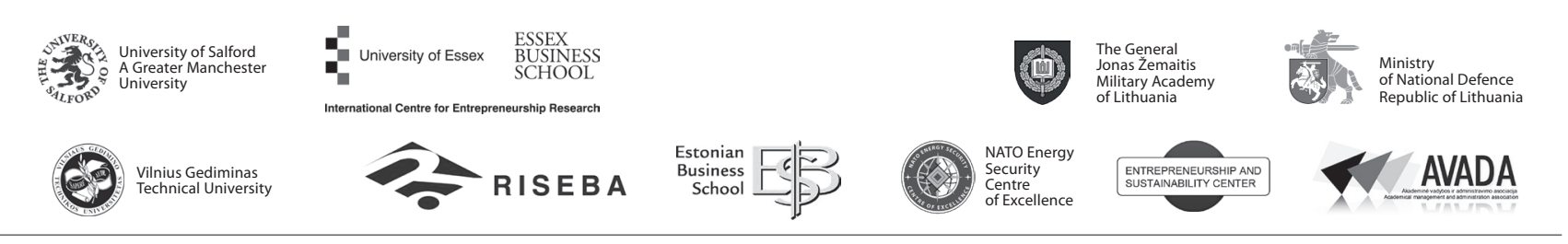

JOURNAL OF SECURITY AND SUSTAINABILITY ISSUES

ISSN 2029-7017 print/ISSN 2029-7025 online

2017 September Volume 7 Number 1

http://dx.doi.org/10.9770/jssi.2017.6.1(8)

\title{
MECHANISTIC, OR BIOTIC ORGANIZATIONS: RESEARCH OF ORGANIZATIONAL PRINCIPLES TOWARDS SUSTAINABILITY OF SOCIAL SYSTEMS
}

\author{
Karel Slinták ${ }^{1}$ \\ ${ }^{1}$ Tomas Bata University in Zlín, nám. T. G. Masaryka 5555, 760 01, Zlín \\ E-mail: ${ }^{1}$ slintak@fame.utb.cz
}

Received 11 December 2016; accepted 25 March 2017

\begin{abstract}
This article deals with the question of how we perceive organizations - as machines for making money, or as living systems with specific needs and objectives. In accordance with these views, a model of a biotic organization has been created with the research aim to measure the level of representation of biotic organizations in the business environment. The model of a biotic organization consists of four principles: amorphous structure, leadership, shared vision and service to its own environment. In practice, the existence of the individual elements of the biotic organization were evaluated by quantitative and qualitative research. Answers were sought and found to the four partial questions put forward, namely: What is the purpose of the existence of the organization? What type of structure is applied in organizations? Is there a shared vision within organizations? Which of these principles, management or leadership, is applied more in practice? The results of the research show that only five percent of organizations in the business environment are biotic organizations. This confirms the research hypothesis that this organizational form is not prevalent in the current economic environment. The low level application of biotic principles reveals that most companies are still organized on the basis of the principles of mechanistic organizations. This is reflected in formal hierarchies, a pyramidal structure and traditional management that create an environment of command and control.
\end{abstract}

Keywords: adhocracy, leadership, living system, mechanistic system, service to society, shared vision

Reference to this paper should be made as follows: Slinták, K. 2016. Mechanistic, or Biotic Organizations: Research of Organizational Principles towards Sustainability of Social Systems, Journal of Security and Sustainability Issues 7(1): 94-112.

http://dx.doi.org/10.9770/jssi.2017.7.1(8)

JEL Classifications: M20, O30

\section{Introduction}

The current perception and conception of organizations as the social products of an industrial society (Čirjevskis 2015; Kaźmierczyk, Aptacy 2016; Tvaronavičienè 2016) has evolved from two simultaneously applied theories. These theories are the theory of mechanistic systems (an organization is closed system) and the theory of living systems (an organization is open system). These two basic approaches have led to the creation of completely different organizational models. The first of these models is known as the "mechanistic organization". This model defines an organization as a machine for making money. The second model is known as the "biotic organization". This model defines an organization as a living organism whereby specific tasks arise from the needs of the external environment. Both the aforementioned models are unique not only for their attitude to the nature of the organization. The properties of these models also indicates that each of them applies a different form of management. While the model of the mechanistic organization applies elements of traditional management (i.e. to be controlled), the model of the biotic organization applies elements of self-management (i.e. to lead myself) and emergency management. 
This non-traditional theoretical definition which stems from the efforts of new science built on the assumptions of vitalism and organicism opens up completely new possibilities for research in the field of management. The intention is therefore to explore the extent of the principles of biotic organizations in practice and to determine the representation of biotic organizations in the organizational population.

\section{Theoretical background}

The model of the mechanistic organization was described in the scientific paper "The Principles of Mechanical Organizations" (Slinták 2013). This concept consists of four elements of classical management, namely the division of labour, bureaucracy, command and control, and profit. A mechanical organization may be defined as a machine for making money. The elements of a mechanical organization were described in the theoretical works of the founders of classical management. The division of labour was already described in 1776 in the book "The wealth of nations" by Adam Smith (Hammer and Champy 1993). Bureaucracy was defined in 1922 by Max Weber. Weber understood bureaucracy as an ideal organizational form of a mechanical organization (Weber 1947). The principle of command and control was described in Taylor's scientific management (Taylor 2011) and Fayol's theory of management (Fayol 1916). These theories were based on the assumptions that organizations are closed systems (in this context we speak about closed system strategy) with deterministic behaviour. The aim of these authors was to search for certainty in their behaviour. Clarity and certainty therefore became the prerequisites for the creation of the ideal conditions for internal arrangements.

Historical analysis reveals that from the 1950s onwards authors started to deviate from efforts to define organizations as mechanical systems and began to examine them in the context of living systems (Gouldner 1959, Bragdon 2009, Burns and Staulker 2000, Luhmann 1986). The attention of authors focused especially on the relationship between organizations and their surroundings. This process started in 1956 with Boulding's theory which defined organizations as open systems for the first time. The new approach called open system strategy created space for the expectation of uncertainty. The authors often summarized their findings through so called organizational forms. These new forms expressed important changes in the conception and perception of organizations and ultimately led to the creation of new organizational models.

In contrast, other authors have failed to describe or explain the concept of a biotic organization. The impetus for the creation of this model was how people perceive companies - as a community of people, or as a machine for making money (Dee Geus, 1997). The theoretical sources that preceded this concept are summarized in the following table (Table 1).

Table 1. Theoretical sources related to the concept of a biotic organization

\begin{tabular}{c|l}
\hline \multicolumn{1}{c}{ Authors } & \multicolumn{1}{c}{ Fundamental ideas } \\
\hline Boulding (1956) & $\begin{array}{l}\text { Organizations are open systems, characterized by a high level of complexity, reactivity and looseness } \\
\text { of coupling among system components. }\end{array}$ \\
\hline Gouldner (1959) & $\begin{array}{l}\text { Organizations can apply two underlying models - a rational and natural system. The rational system } \\
\text { defines organizations as instruments which can be consciously shaped and molded to accomplish a } \\
\text { given end. A natural system defines organizations as an organic system, as collectivities that evolve } \\
\text { via spontaneous, indeterminate processes. }\end{array}$ \\
\hline $\begin{array}{c}\text { Burns and Stalker } \\
(1961,2000)\end{array}$ & $\begin{array}{l}\text { There are two important organizational approaches - mechanical and organic. Organizations located } \\
\text { in a dynamic environment must be organic systems. }\end{array}$ \\
\hline Thompson and Hawks (1962) & $\begin{array}{l}\text { An ad hoc organization usually emerges to overcome the effects of large-scale disasters in } \\
\text { communities. This organization may be labelled as being a synthetic organization. }\end{array}$ \\
\hline Garrison (1967) & $\begin{array}{l}\text { Companies in more complex environments are more likely to be highly differentiated in structure } \\
\text { and devote more resources to coordination. Companies in less complex environments are less } \\
\text { differentiated and more easily integrated. }\end{array}$ \\
\hline Thompson (1967, 2001) & $\begin{array}{l}\text { Thompson suggested a "levels" model in which he proposes that: (1) all organizations are, by their } \\
\text { nature, open to the environment; (2) all organizations must adopt to their environments by crafting } \\
\text { appropriate structures; (3) organizations are differentiated systems. }\end{array}$ \\
\hline
\end{tabular}




\begin{tabular}{c|l}
\hline Katz and Kahn (1978) & $\begin{array}{l}\text { The authors proposed that the typology of an organization is based on genotypic and second factors. } \\
\text { According to genotypic factors there are four types of organizations: (1) Productive organizations; } \\
\text { (2) Maintenance organizations; (3) Adaptive organizations; (4) Managerial-political organizations. }\end{array}$ \\
\hline Mintzberg (1979) & $\begin{array}{l}\text { How an organization actually functions? The results of Mintzberg's synthesis were five basic } \\
\text { configurations: Simple Structure; Machine Bureaucracy; Professional Bureaucracy; Divisionalized } \\
\text { Form; and Adhocracy. }\end{array}$ \\
\hline
\end{tabular}

The return to the thesis of the organization as a living system was caused by the significant economic and social changes that occurred in the 1990s. At that time, it was already apparent that company size cannot be an independent variable function of performance. This is because at times when demand exceeds supply, enterprises cannot have the character of predictable machines in an environment that is close to biological complexity. In their work, many authors began to explore terms reflecting the area of biology, such as the immune system (Hammer, 2002); homeostasis (Senge, 1990); dynamic complexity (Forrester, 1987); cyclical systems and the circular economy (Senge, 1990, 2007); system archetypes (Senge 1990), the DNA of a company (Bateson, 1972; Hock, 2000); the soul of an enterprise (Handy, 1997); network structure (Kelly, 2007); synergy and holism (Covey, 2010, 2013); Harung 2004; Senge, 2007, 2009); and collective intelligence (Hamel \& Breen 2008; Hamel 2013). This change in terminology implies a gradual passing from the philosophy of natural sciences to the philosophy of biological sciences (Sandow \& Allen, 2005). New organizational models began to appear on the back of these changes. These models understood organizations as being living systems rather than mechanistic systems. An example is the view of John Kotter (2000) summarized in Table 2.

Table 2. Two types of organizations

\begin{tabular}{|c|c|c|}
\hline & Traditional organization of the $20^{\text {th }}$ century & Modern organization of the $21^{\text {st }}$ century \\
\hline Structure & $\begin{array}{l}\text { - Bureaucracy } \\
\text { - Pyramid structure } \\
\text { - The task of management is to control. } \\
\text { - The rules and procedures create a complex network of arti- } \\
\text { ficial dependencies }\end{array}$ & $\begin{array}{l}\text { - Non-bureaucratic structure } \\
\text { - Flat structure } \\
\text { - The task of management is to lead. } \\
\text { - The rules and procedures ae created in minimal cases. }\end{array}$ \\
\hline Systems & $\begin{array}{l}\text { - Information system is insufficient for performance meas- } \\
\text { urement. } \\
\text { - Unwillingness to share information on financial results. } \\
\text { - Qualifications determine work assignment. }\end{array}$ & $\begin{array}{l}\text { - Information system is a complex system for performance } \\
\text { measurement. } \\
\text { - Transparency - sharing information on financial results. } \\
\text { - Talent, skills and abilities determine work assignment. }\end{array}$ \\
\hline Culture & $\begin{array}{l}\text { - Introspective culture } \\
\text { - Centralization } \\
\text { - Rigid decision-making process } \\
\text { - Clientelism } \\
\text { - Avoiding risk }\end{array}$ & $\begin{array}{l}\text { - Open culture } \\
\text { - Empowerment } \\
\text { - Quick decision-making process } \\
\text { - Meritocracy } \\
\text { - Open to risk }\end{array}$ \\
\hline
\end{tabular}

Source: Kotter (2000)

In addition to Kotter, there are other authors who summarize their findings into new organizational forms or models. Table 3 recapitulates the models that influenced the creation of the concept of biotic organizations. 
Table 3. Organizational models

\begin{tabular}{|c|c|}
\hline Authors & Organizational model (and/or significant idea) \\
\hline Handy (1989) & $\begin{array}{l}\text { The organizations of the future are the "three Is" - Information, Intelligence and Ideas. In those } \\
\text { organizations, the demands related to people's management are big - "The wise organization is already } \\
\text { conscious that its shrewd personnel cannot be easily defined as employees or managers, but as individuals, } \\
\text { specialists, liberal professionals, executives or leaders, and those people and the organization itself also need } \\
\text { to have an obsession for the search of the learner if they want to follow the rhythm of change". }\end{array}$ \\
\hline Senge (1990) & $\begin{array}{l}\text { The learning organization is formed by five disciplines: personal mastery; system thinking; mental models; } \\
\text { team learning; and shared vision. }\end{array}$ \\
\hline $\begin{array}{l}\text { Kotter and Heskett } \\
\quad(1992)\end{array}$ & $\begin{array}{l}\text { Corporate culture can have a significant impact on long-term economic performance. Value based } \\
\text { organizations have a strong culture which emphasizes all three interests (customers, shareholders, } \\
\text { employees). A strong culture also means a high level of conformity values and business methods. }\end{array}$ \\
\hline $\begin{array}{l}\text { Collins and Porras } \\
\qquad(1994)\end{array}$ & $\begin{array}{l}\text { Visionary companies were defined as those organizations which have achieved lasting success for several } \\
\text { decades. It was found that the long-term success of these companies related to synergy of stability (core } \\
\text { ideology) and change (envisioned future). The authors shattered many myths, particularly about the goal of } \\
\text { maximizing profits. Visionary companies are not just organizations, they are institutions in the richest sense of } \\
\text { that word, for, as Collins and Porras put it, "they have woven themselves into the very fabric of society." }\end{array}$ \\
\hline Kelly & $\begin{array}{l}\text { Organizations must be formed by biological means. A natural metaphor for organizational complexity is } \\
\text { something like a network. Network organizations reflect the shift from monolithic, vertical, homogenized } \\
\text { institutions to extremely decentralized, fragmented, heterogeneous and flat organizations. The new type } \\
\text { of organization is characterized by greater uncertainty and ambiguities in relation to who is a part of the } \\
\text { organization and who is not. }\end{array}$ \\
\hline Hock $(2000,2005)$ & $\begin{array}{l}\text { The chaordic organization is a new organizational form. The word "chaordic" refers to a system of } \\
\text { organization that blends the characteristics of chaos and order. Generally speaking, chaord means any } \\
\text { self-organizing, adaptive, nonlinear complex system, whether physical, biological, or social, in which its } \\
\text { behaviour exhibits the characteristics of both order and chaos or loosely translated to business terminology, } \\
\text { cooperation and competition. }\end{array}$ \\
\hline Drucker & $\begin{array}{l}\text { There are three dimension of enterprise: companies like economic organizations (American model); } \\
\text { companies like organizations of human beings (Japanese model); and companies like social organizations } \\
\text { (German model). }\end{array}$ \\
\hline Harung (2004) & $\begin{array}{l}\text { There are four stages of organizational development which lead to breakthrough improvements in } \\
\text { organizational performance: (1) Task based management; (2) Process based management; (3) Value based } \\
\text { management; and (4) Development based management. }\end{array}$ \\
\hline Covey (2010) & $\begin{array}{l}\text { Whole person paradigm consists of four dimensions which are the body, heart, mind and spirit. This } \\
\text { paradigm is the basis for the better understanding of humans as well as organizations. The organizational } \\
\text { model based on principles of the whole person paradigm contain these elements: (1) Vision; (2) Discipline; } \\
\text { (3) Passion; and (4) Conscience. }\end{array}$ \\
\hline $\begin{array}{c}\text { Prahalad and } \\
\text { Ramswamy (2013) }\end{array}$ & $\begin{array}{l}\text { A nodal company coordinates the activities of many suppliers, users, and consumers to make up a network of } \\
\text { experience. Basically, this organizational form creates and develops a platform (ecosystem) which leads to } \\
\text { the formation of co-creational experience. In such networks the company no longer takes first place, instead } \\
\text { the experience of the individual consumer comes first. }\end{array}$ \\
\hline
\end{tabular}

\section{Research aim, data and methods}

This article aims to create a model of a biotic organization and to measure the extent to which the principles of a biotic organization are applied in practice in Czech companies. The result of these efforts will be the characterization of biotic organizations in the economic environment of the Czech Republic, based on verification of the following research question: "Do biotic organizations represent more than $10 \%$ of those in the organizational population?" The model of a biotic organization will be based on an analysis of the theoretical bases of other authors. The procedure for creating a model of a biotic organization is described in Section 3.

\section{Quantitative research}

The respondents were randomly selected through the Inform database. Data were collected by means of an interactive questionnaire. The questionnaires were distributed in one of two ways, either by email or through a personal visit. The respondents all came from Czech companies and worked at middle or top management level. For the purpose of this survey it wasn't necessary to determine the minimum company size. Companies which participated in the research were divided into four categories according to European Union (EU) legislation. 


\section{Sample statistics}

Respondents submitted 56 surveys through the web-based system (response rate $=6.6 \%$ ). Data resulting from this quantitative research was processed in the form of descriptive statistics and then categorized into absolute and relative frequencies. Some data tables were converted into graphic form. Some data were analysed using the Pearson test. Hypotheses were tested on a level of significance of $\alpha=0.05$. A p-value lower than the confidence level resulted in the rejection of the null hypothesis. The null hypothesis claims there is no association between the variables. The calculations were performed in Excel.

The very low response rate and relatively small statistical sample could have a negative impact on the research results. It is for this reason the authors had to determine the minimal number of respondents (sufficient representative sample). It is possible to calculate this according to the formula known as the sample size calculation that can be found in Cochran (1977):

$$
n=\frac{Z^{2} p(1-p)}{d^{2}}
$$

Where:

$\mathrm{t}_{\alpha}$ is the coefficient of reliability for the selected reliability $\alpha$ (for desired confidence level $90 \%$, z-score is $1.645)$,

$\mathrm{p}$ is the estimate of the relative frequency of surveyed criteria in the basic sample $(0,5$ used for sample size needed),

$\mathrm{d}$ is the required permissible error,

If we require $90 \%$ reliability with a permissible error of $11 \%$, then the minimum number of surveyed respondents is the following:

$$
n=\frac{1,645^{2} * 0,25}{0,11^{2}}=55,90960744
$$

According to the calculation above the minimum number of surveyed respondents for a representative sample is 56 . Of the total 850 companies contacted, exactly 56 surveys were returned. Although we can only speculate why the response rate was so low, we believe that the response rate could have been influenced by the methods by which the questionnaire was distributed. The majority of the companies surveyed were contacted through email correspondence.

The basic parameters of the quantitative research - the details of the statistical sample including selected characteristics of the surveyed companies - are summarized in Table 4.

Table 4. Basic parameters of the quantitative research

\begin{tabular}{lcc}
\hline \multicolumn{1}{c}{ Number of respondents } & Freq. (absolute) & Freq. (relative) \\
\hline Frequency of organizations by size: & 56 & $6.6 \%$ \\
1. Large enterprises & & \\
2. Medium-sized enterprises & 11 & $20 \%$ \\
3. Small enterprises & 24 & $43 \%$ \\
4. Microenterprises & 12 & $21 \%$ \\
Frequency of organizations by output: & 9 & $16 \%$ \\
1. Primary sector (raw materials) & 4 & $7 \%$ \\
2. Secondary sector (manufacturing) & 28 & $50 \%$ \\
3. Tertiary sector (services) & 24 & $43 \%$
\end{tabular}




\section{Frequency of age range of organizations:}

1. 0 -10 years

2. 11-20 years

3. 21-30 years

4. 31-40 years

5. 41 and more

$\begin{array}{cc}5 & 9 \% \\ 32 & 57 \% \\ 2 & 3 \% \\ 1 & 2 \% \\ 16 & 29 \%\end{array}$

The field of research was aimed at answering the following four questions:

1. What is the purpose of the existence of business organizations?

2. What type of structure is applied in business organizations?

3. Is there a shared vision in business organizations?

4. Which of these principles, management or leadership, is applied more in practice?

Our quantitative research was limited by very strong standardization. Most questions were of the closed type. Respondents could choose from two variants (research question 2, 3 and 4) or three variants (question 1). They could choose only one option. Some terms contained in the questionnaire were explained in person or by using the enclosed terminology. For the question regarding the shared vision, responses were corrected by control question so as to reduce the subjective tendencies of the respondents (biased answers). Subjectivity was also eliminated by the fact that the respondents could not know what the correct answer was because they were unaware of the fact that the objective of the research was focused on identifying biotic principles.

\section{Case studies}

The very strong standardization of the quantitative research was partially reduced by information obtained through case methodology. Utilizing this methodology meant we could take into account practices in selected companies. A list of the observed companies, their unique practices and the research subject is presented in Table 5 .

Table 5. Observed companies

\begin{tabular}{lcc}
\hline \multicolumn{1}{c}{ Observed companies } & Unique practices & Field of research \\
\hline W.L. Gore & Lattice structure & Network structure \\
\hline Harley Davidson & Circle structure & Network structure \\
Semco & Antistructure & Network structure \\
\hline Visa & Radical decentralization & Network structure \\
Morning Star & Agreement of colleagues & Self-management \\
W.L. Gore & Reciprocal obligation & Self-management \\
Semco & Participation & Self-management \\
\hline ABB & A rule of 50. & Shared vision \\
W.L. Gore & Principle of 200 & Shared vision \\
Semco & Production cells & Shared vision \\
Google & Self-managed teams & Shared vision \\
\hline FAVI & Know-Why & Culture and principles \\
W.L. Gore & Culture of trust & Culture and principles \\
SOL & Culture of freedom & Culture and principles \\
Semco & Democratic workplace & Culture and principles \\
IDEO & Attitude of wisdom & Culture and principles \\
\hline
\end{tabular}

\section{Principles of biotic organization}

The models of a biotic organization have been affected by theories (see Table 1) which define such organizations as open, dynamic systems. The differentiation between these systems depends on the complexity of the environment. In this concept, organizations are living systems which were born in conditions of uncertainty, of their own free will and subject to interdependencies. A biotic organization can be defined as a social organism which takes different forms depending on the task that it fulfils in its environment. There are many organiza- 
tional models which became the prototypes for biotic organizations (see Table 3). The synthesis of these models led to the creation of images of four organizational dimensions that reflect the organizational needs of a biotic organization: the need to live (adaptability), to love (stability), to learn (dynamics) and to serve (usefulness). The final shape of the model of a biotic organization arose mainly from Senge's concept of a learning organization (Senge 1990) and Covey's perception of organizations as holistic systems consisting of four organizational dimensions (Covey 2010).

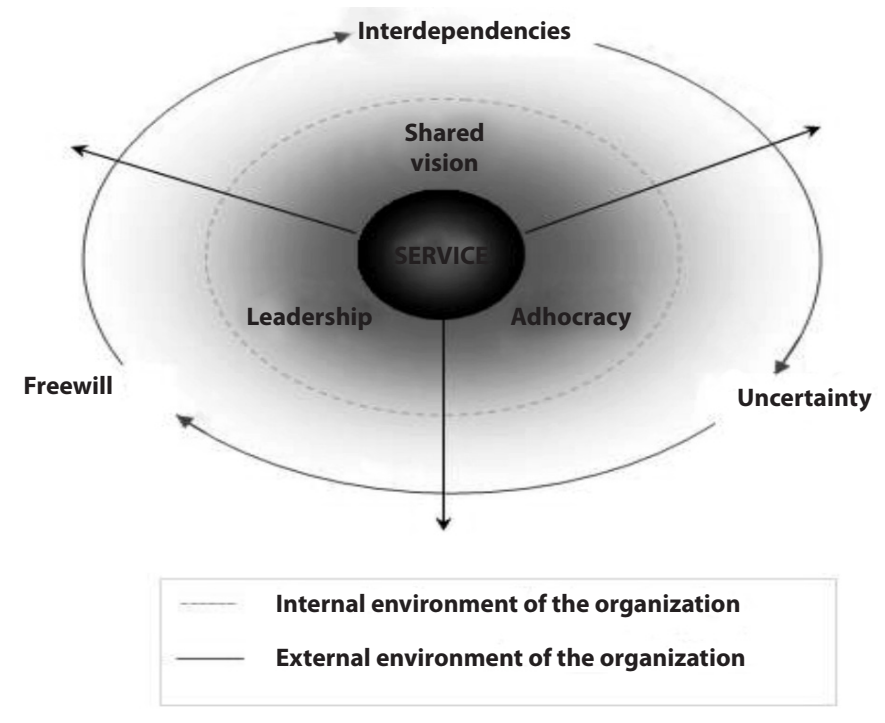

Fig. 1. Principles of a biotic organization.

The model of a biotic organization arises from the technology of postmodern management, which takes into account changing environmental conditions, reflects new assumptions, and recognizes the principles of living systems rather than the principles of mechanistic systems. These principles include an amorphous structure (i.e. adhocracy), leadership, shared vision and service (to its own environment). Each of these principles is based on natural law, because all living systems are of a cyclical and self-regulating character. In natural communities there is often the phenomenon of collective intelligence (by analogy with human systems, it can be understood as a certain form of shared purpose observed, for example, in birds or fish); they are self-organized, which means that they are not controlled by others, but rather self-organized through their own unconscious instincts. Finally, each animal fulfills its specific task according to the environment in which it occurs. These principles are in some sense a response to the specific characteristics of the external environment, illustrated in the Figure 1.

In practice, these principles may take different forms. Shared vision is the result of system thinking, on the basis of which the dynamic complexity of the world of interdependencies can at least be partially understood. It sets out a common path and evokes a feeling of partnership and shared purpose. The common goal defines the limits of individual behaviour. In a sense, it replaces the original philosophy of management based on the fragmentation of the organization, in which people are working on the basis of functional classification in order to achieve only partial goals (not companywide goals). The amorphous structure creates the internal form of an organization, depending on the task which the organization is engaged in. It is thus a specific kind of adhocracy, which is the counterpart of bureaucracy (Mintzberg, 1979). This approach to the internal configuration of the organization is based on the assumption of the instability and unpredictability of the external environment. It creates a high degree of freedom inside the organization. In practice, this form of organization spread particularly in the creative industries. Structuring for a particular purpose, for example, is typical for Hollywood movie studios, as well as for companies that deal with advanced technologies, including Apple and Google. These companies face enormous pressure from competitors and powerful dynamics in the development of new technologies. In this case, it is obvious that the new technology of postmodern management can be directly enforced by the specific circumstances of the environment. 
Biotic organizations are harmonized and, above all, have a culture of trust (and freedom), which gives people considerable power and freedom to focus on what they want to do (Carney \& Getz, 2013). This type of culture has been identified in the companies W.L. Gore, Semco, SOL, FAVI, IDEO. The amorphous structure, however, can't exist without institutionalized moral authority. As Carney with Getz discovered when they researched freedom in work, real leaders become guardians of culture in a more free working environment. Companies applying this specific culture include FAVI, IDEO, SEMCO, SeaSmokeCellars, and, previously, Radica Games. The authority of a biotic organization is thus institutionalized by leadership, i.e. a new management function that puts an emphasis on enhancing powers in order to release human potential through specific types of motivation in the form of self-management. However, the core of a biotic organization resides in the ability to reveal a deeper purpose, which grows out of the whole person paradigm. This paradigm can be simply defined in the sense of the attitude reflecting "our world", not "my world". Therefore, biotic organizations must seek the purpose of their existence in the external environment. High performance is achieved only if organizations become excited about something more than simply making a profit (Google wants to change the world, Apple wants to create revolutionary products, Walt Disney wants to bring happiness to people, Whole Foods Market wants people to improve their health and well-being etc.). Simply put, biotic organizations have a purpose that provides their workers with a deeper motivation.

The nature of these organizations requires us to look at them as organs of society with clearly identifiable characteristics, these being an amorphous structure, leadership, a shared vision, and service to one's own environment. On the basis of these attributes, we can explore the extent to which current organizations approach an organizational form based on biotic principles, and how far such biotic organizations are representative of the business environment.

\section{Results and discussion}

The quantitative research aimed at mapping the occurrence of biotic principles sought to answer the following: 1. What is the purpose of the existence of business organizations? 2. What type of structure is applied in business organizations? 3. Is there a shared vision in business organizations? 4. Which of these principles, management or leadership, is applied more in practice.

As we can see in the following table (Table 6), the logic of research was closely related to the categorization, which emerged from the model of the biotic organisation.

Table 6. The research questions and categorization.

\begin{tabular}{cccc}
\hline $\begin{array}{c}\text { Characteristics of the } \\
\text { external environment }\end{array}$ & $\begin{array}{c}\text { Principles of biotic } \\
\text { organization }\end{array}$ & Research questions & Categorization \\
\hline Wisdom & Adhocracy & $\begin{array}{c}\text { What type of structure is } \\
\text { preferred in practice? }\end{array}$ & Adhocracy/hierarchy \\
\hline Uncertainty & Shared vision & $\begin{array}{c}\text { Is there shared vision in } \\
\text { organization? }\end{array}$ & Shared vision/individual goals \\
\hline Interdependencies & Leadership & $\begin{array}{c}\text { Which of these principles is } \\
\text { applied more in practice? }\end{array}$ & Leadership/management \\
\hline Free will & & &
\end{tabular}

\subsection{What is the purpose of existence of business organizations?}

Classical economic theory defines the company as a machine for making money. According to this theory, each enterprise should follow a simple rule: to use resources (including human) in order to maximize earnings. In view of this goal, the enterprise is the creator of resources, the purpose of which is to transform inputs into outputs. Of course, outputs must exceed inputs. In financial terms, this means that a positive economic result is achieved, one which usually reflects accounting profit rather than economic profit. 
An alternative theory, which is based on the profit motivation, involves the idea of the market value of the company. However, because the market value of a company grows when the company makes a profit and falls when the company makes a loss, it can be argued that the goal of increasing market value springs from the same base as the profit motive. These are, therefore, two theories describing the same idea. In both cases, performance is measured by short-term, and usually only financial, indicators. In the background of these concepts is the assumption that every enterprise is a machine that consists solely of the economic dimension.

Research conclusions by Collins and Porras (1994) summarized in the book entitled Built to Last, as well as the famous study of the longevity of organizations conducted by Royal Dutch / Shell in 1983 (Handy, 1997; Senge, 1990), however, show that the ability to exist for a long time in a business environment deviates from the mere satisfaction of economic needs. The function of each organization, as an organ of society, must be to satisfy the specific needs of the external environment. The purpose of the existence of a biotic organization is to serve society (its own environment). This definition of the corporate sense corresponds with research findings according to which the vitality of organizations is very closely related to the ability of organizations to satisfy the needs which emerge from the external environment. In contrast to traditional economic theory, the criteria of success in the case of biotic organizations lie only in the external environment. The purpose of biotic organizations, therefore, will always be limited by the external environment. The conditions, characteristics and requirements of this environment can redefine the business tasks and change the default mission of these organizations. The primary function of these organizations is, therefore, to reveal this task, which requires not only external orientation toward the customer, but also internal orientation in the form of the creation of a work environment that reflects the needs and interests of other stakeholders, which are associates and owners. This demonstrates the interdependence of biotic principles, when a deeper sense cannot be created without leadership, an open structure, and shared vision.

The three goals are clearly rooted in the practice of contemporary organizations. They show their attitude to their customers, employees, shareholders, and society as a whole. Surprisingly, the survey revealed considerable orientation towards the external environment (41\%) and a lower than expected proportion of companies oriented towards the profit motive (29\%). The following table presents the results of the research (Table 7).

Table 7. The purpose of existence in practice

\begin{tabular}{ccc}
\hline $\begin{array}{c}\text { What is the purpose of existence } \\
\text { of your organization? }\end{array}$ & Relative in (\%) & p-value (1-a = 0.95) \\
\hline Earning & 28.57 & 0.963689357 \\
\hline Market value & 30.36 & 0.751807493 \\
\hline Service to society & 41.07 & 0.921056892 \\
\hline
\end{tabular}

Source: Authors research.

Organizations whose purpose of existence is defined as service to society are still in the minority (41\% of the total). Among other things, this means that the majority of organizations (more than $50 \%$ ) are too focused on the internal environment and ignore the external one. On the basis of research findings, we can conclude that most companies are, in terms of their actual purpose, still defined as instruments for making money ( $59 \%$ of the total). 


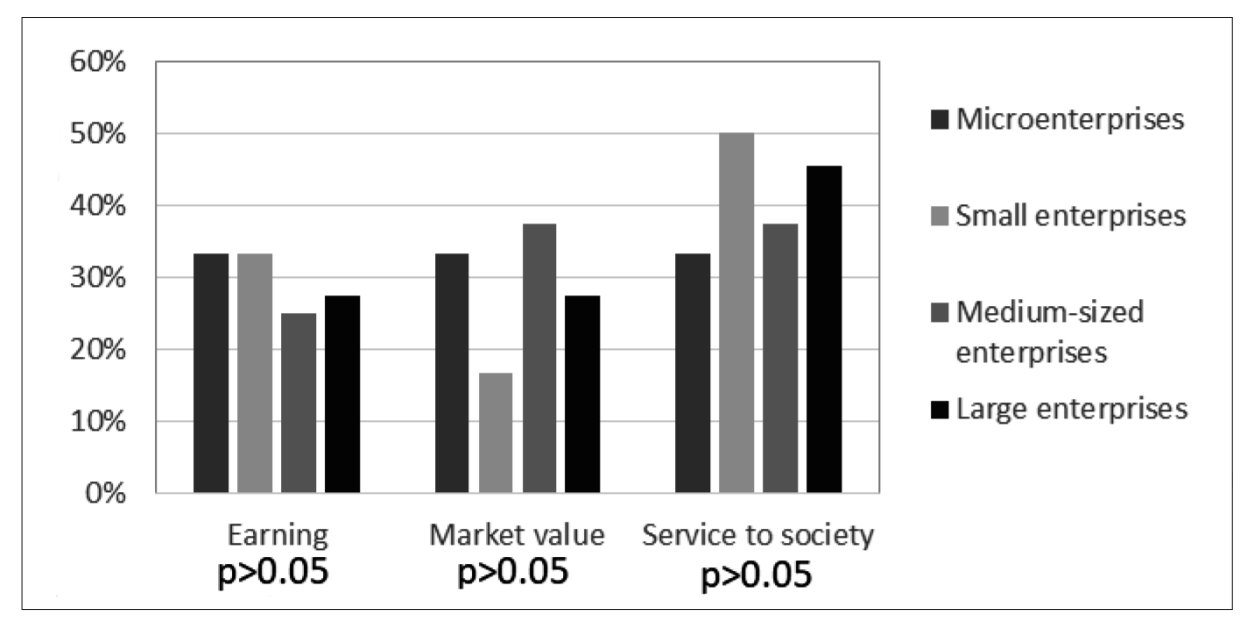

Fig. 2. The purpose of existence within the context of company size.

It was also found out whether there is a positive relationship between company size and the purpose of existence $\left(\mathrm{H}_{0}\right.$ : There is not a significant positive relationship between company size and the purpose of existence of business organizations). The results of this research have shown that there were not statistically significant differences between company size and individual purposes of existence, which was confirmed by the values of the test criteria (see Fig. 2).

\subsection{What type of structure is applied in business organizations?}

Three basic types of structures have been developed in the economic environment over the last three hundred years. These structures are the haphazard structure, the hierarchical structure, and the amorphous (i.e. network) structure. Each of these structures arose in a specific environment. The haphazard structure was the result of the agrarian society that predominated from the 17th to the 19th centuries. It began to transform into industrial society from the 19th century. At that time, people created the first modern business organizations organized on the basis of a hierarchical structure. At present, however, an entirely new kind of structure is emerging, one that symbolizes the age of information. These structures are amorphous, or network structures. In W. L. Gore, this new type of organization is referred to as a lattice structure (Hamel \& Breen 2008; Hamel 2013; Harung 2004). In Semco, people were organized according to circular structure (in the nineties) and later, this company stopped to use organizational structure and hit the road to uncertainty (Semler 2011). In this context, we can speak about antistructure (see Hammer 2002). In Harley-Davidson, circular structures were also established (Senge 1990). No matter what this new type of structure is called, they share one particular feature; that is, they are not built on the principles of formal hierarchy, but rather on a network of relations, which is defined by reciprocal obligations towards colleagues and co-workers.

Research work therefore focused on two basic organizational approaches, namely pyramid schemes and network configuration settings, in order to determine to what extent network structures are applied in practice in current enterprises. Simultaneously, the authors attempted to find out whether there is a significant positive relationship between company size and the type of structure $\left.(\mathrm{H} 2)_{1}\right)$. The Results are given in the table below (Table 8).

Table 8. Typology of structures in practice

\begin{tabular}{c|c|c}
\hline $\begin{array}{c}\text { What kind of structure is applied } \\
\text { in your organization? }\end{array}$ & Relative in (\%) & p-value (1-a $=0.95)$ \\
\hline Amorphous structure & 14.29 & 0.325542258 \\
\hline Hierarchical structure & 85.71 & 0.901624534 \\
\hline
\end{tabular}


The research indicated that only one in seven organizations is organized by means of a network without a stiff formal hierarchy, despite a radically changing ecosystem, which causes the increasing institutional collapse of bureaucratic organizations built on formal hierarchies. Our research findings from previous table also show that there is not a significant positive relationship between company size and the type of structure (see Fig. 3).

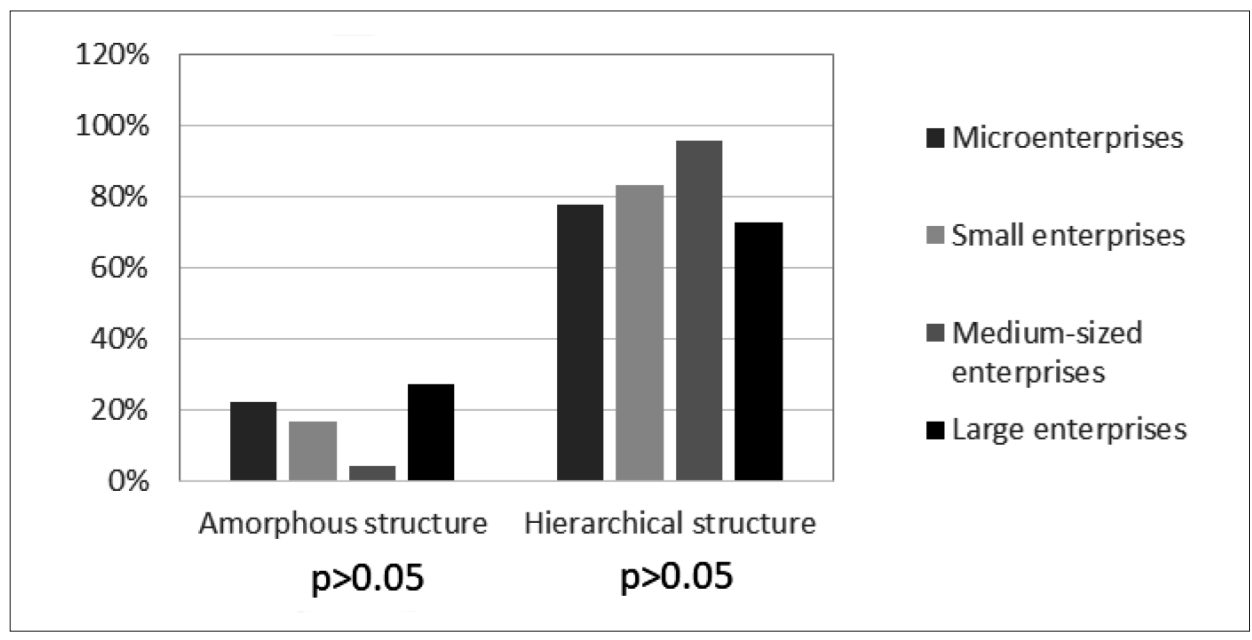

Fig. 3. The type of structure within the context of company size.

In the current environment, it appears that bureaucracy is not able to respond quickly enough to the frequent changes in the environment. The proof of this assertion can be seen in the recent past. It was the collapse of the Soviet Union and other centrally controlled economies, as well as the bankruptcy of the automobile giant General Motors (GM), that provided a great deal of knowledge about the limits of hierarchical structures. Both of these examples are of identical origin. They were social systems built on the technology of traditional management, which does not take into account the conditions of discontinuity, uncertainty, and variability.

Nowadays, many organizations strive to take advantage of the effects of synergy. However, these effects are related to the way individual elements within the system are organized. Experience in the building of sports teams suggests that the effects of synergy are achieved by the so-called concept of aligning (see Senge and Carstedt (2001), Covey 2010, 2013). The essence of aligning is ensuring that team members strive to achieve the same goal. Having a common goal affects behaviour in such a way that the energy of individuals is multiplied rather than fragmented. Aligning also demonstrates that a network structure cannot work effectively without the existence of a shared vision, which is an integral part of it.

In practice, the outlines of a network structure can be seen in Visa Interactive, W. L. Gore, Semco, and Morning Star, and also partly in Google and Apple. These companies have created a new trend: management without a formal hierarchy. Obviously, this does not mean that there isn't some form of hierarchy, but the hierarchy has, rather, a more natural than formal character, because people working in these companies become leaders due to their competence and knowledge, and not on the basis of contacts and mutual sympathy. In most cases, leaders are elected by members of teams or working groups, as well as recalled by them. The teams can also determine who will work in them. In these organizations, there are no superiors or subordinates, only associates and colleagues. People acquire the freedom (to do what they want), which is balanced by reciprocal obligation in W. L. Gore or the agreement of colleagues in Morning Star (Hamel 2011).

Based on the research of organizational practices, the abovementioned companies have acquired two basic characteristics of amorphous structures: firstly, structures without a formal hierarchy require a common focus (i.e. the creation of a shared vision as a common goal); secondly, they require the identification of operating principles that reinforce core purpose and values, namely freedom, openness, transparency, and responsibility. These conditions, which are related to the principle of shared vision and leadership, were examined in the areas of alignment and cohesion. 


\subsection{Is there shared vision in business organizations?}

According to our research, most organizations ( $71 \%$ of respondents) have a vision about the future direction of their business. However, this vision does not always lead to an aligned system. The level of inner harmony affects the organization's ability to share its purpose and to evoke a feeling of partnership and solidarity. Alignment of the enterprise requires, apart from a deeper sense and amorphous structures, also the ability to share its vision. If we look at mechanistic organizations, we find that these organizations cannot really communicate. They can only transmit information from top to bottom. They create visions, but the visions are not compatible with the personal visions of individuals. These organizations do not achieve internal harmony, as individuals tend to move in different directions (Kiefer and Stroh 1983).

The research was therefore aimed at mapping not only an organization's ability to create a vision, but also their ability to share that vision, the ability to communicate and to seek a common path or to define a common direction. The results of our research are presented in following table. It was found that more than $60 \%$ of organizations which create a vision ( $71 \%$ of organizations from the sample) are not able to communicate their vision. In most cases, the vision takes the form of either a financial target or a list of positive values or corporate policies. It is a tool of top management rather than an organizing principle that would support the creation of an environment of creativity and collaboration.

Table 9. Shared vision in practice.

\begin{tabular}{c|c|c}
\hline $\begin{array}{c}\text { Is your vision shared throughout } \\
\text { the organization? }\end{array}$ & $\begin{array}{c}\text { Relative } \\
\text { in (\%) }\end{array}$ & $\begin{array}{c}\text { p-value } \\
(\mathbf{1 - \alpha}=\mathbf{0 . 9 5 )}\end{array}$ \\
\hline Yes & 39.29 & 0.483477669 \\
\hline No & 60.71 & 0.661992811 \\
\hline
\end{tabular}

Source: Authors research.

In our research, we also tested whether there is a positive relationship between company size and shared vision $\left(\mathrm{H} 3_{0}\right.$ : There is not a significant positive relationship between company size and shared vision; $\mathrm{H}_{1}$ : There is a significant positive relationship between company size and shared vision). According to the values of the test criteria, we can state that there are not statistically significant differences between company size and the ability to communicate (share) vision (see Fig. 4).

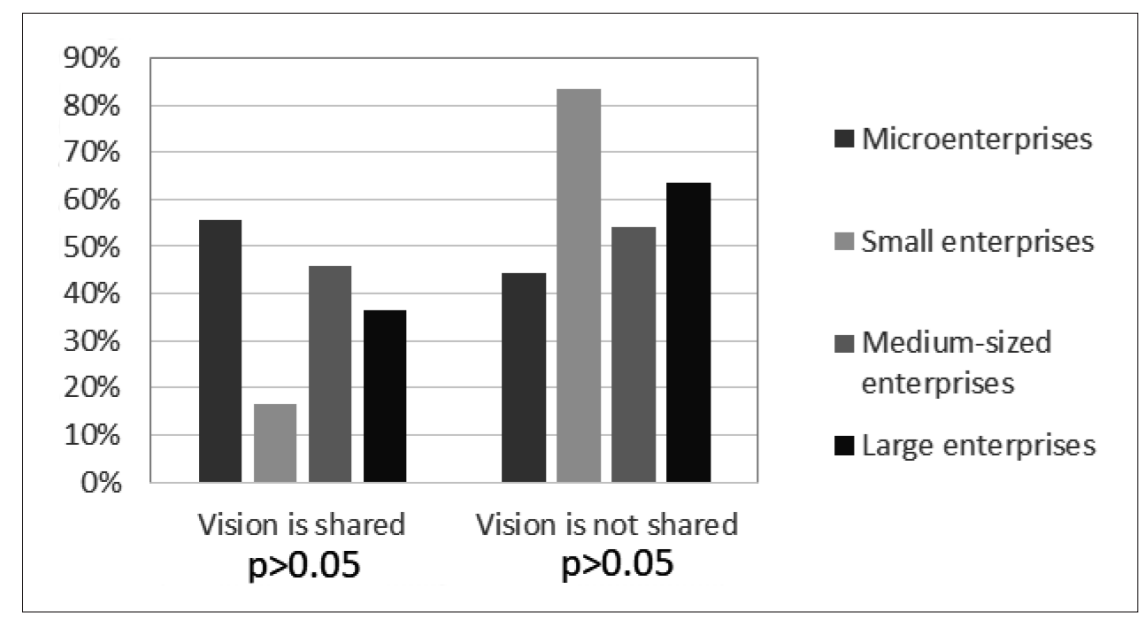

Fig. 4. Shared vision within the context of company size.

The research data supported one of the basic assumptions, according to which the application of the principles of mechanics (we may understand them as traditional management practices) limit the true potential of organizations. Great results cannot be achieved without the alignment of individual parts with the whole. This special 
conformity can be called metaphorically the conformity of souls, which releases the so-called " $\boldsymbol{E}$ factors" (energy, enthusiasm, effort, excitement, excellence) (Handy 1997). The E factors are released by those organizations that combine their own values and goals with the values and goals of individuals. These are companies that are able to apply the principle of biotic organization known as shared vision. It is coincidentally the same principle that has been detected in enterprises encouraging freedom at work (Carney \& Getz 2013). In practice, the atmosphere of mutual sharing and understanding is present in smaller organizational units (see Figure 5), where the "rule of ten" is preserved. This rule is related to the principle of confidence, which is obviously limited by the number of people which an individual can trust, based on personal experience. Simply put, I can't trust someone I do not know. Previous research focused on the performance of people in working groups has revealed that the best results are achieved in relatively small working groups, so-called specific attractors (i.e. 8-12 people) (Kelly 2007), in which people know each other and therefore can build relationships based on mutual confidence without the use of compensators in the form of impersonal control mechanisms, which involve additional social and financial costs.

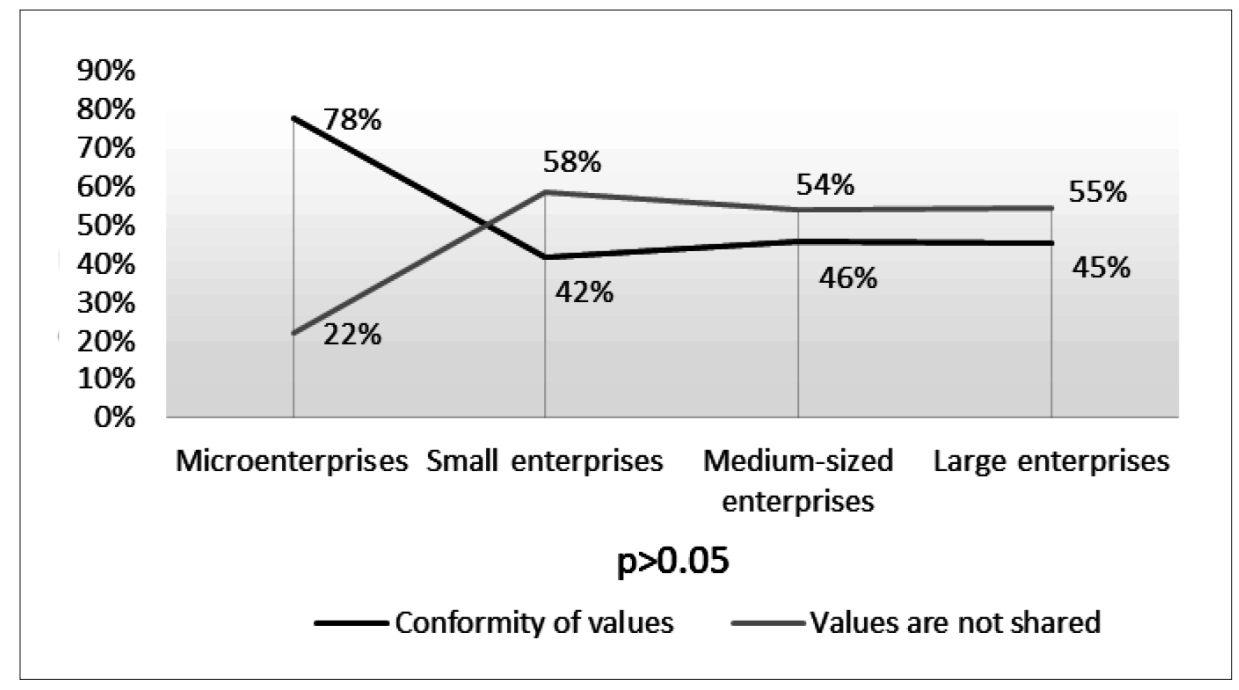

Fig. 5. Conformity of values and objectives in practice.

If we build on the practical knowledge of some companies, we can identify, for example, a "rule of 50" applied in the Asea Brown Boveri company, which employs 250000 people, divided into more than 5000 units. These departments are further divided into basic units comprising an average of forty-five people. W. L. Gore is organized on the principle of 200, according to which each production unit should comprise no more than 200 people. (It must be noted that each unit is formed by many small creative teams constructed on the basis of personal responsibility, which means that each co-worker can determine what to do, where to do it, and with whom. For this purpose, a specific structure known as the lattice structure was created) (Hamel \& Breen 2008). Simultaneously, individual organizational units are organized into industry-related clusters, so that the company as a whole does not lose synergies resulting from intensive, interdisciplinary, and cross-functional communication. The organizing principle limiting the size of organizational units was also reported in the Brazilian company Semco, which decided in the late nineties to organize production at its factories according to production cells including a maximum of 24 workers and 1 coordinator (Semler, 2011). Google, which attracts considerable attention with respect to its rapid development and economic success, excels in the formation of ultra-thin structures consisting of self-managed teams of just 3-4 members (Hamel 2013).

These practices indicate the efforts of these organizations to avoid the hidden costs of traditional management based on the principles of mechanics (the cost of mistrust resulting from the implementation and maintenance of control mechanisms) and at the same time so unwittingly they took into account principles of the biotic organization that encourage openness, transparency, collaboration, and especially confidence. The shared purpose observed in organizations with ten or fewer employees demonstrates the importance of a personal approach to 
people and takes into account the importance of the freedom that people need in order to be able to identify with the company itself and especially to be able to develop and grow.

It turns out that in the light of practical experience, organizational size affects the alignment of the whole system. Large organizations have considerable difficulties in reconciling individual parts and, thus, behave as a single unit. The absence of shared purpose in larger organizations results in insufficiently developed system thinking on the part of managers and the inability to create a process of shared vision. There may also be an unwillingness to lead arising from an excess of traditional management. This assumption will be verified in the next chapter.

\subsection{Which of these principles, management or leadership, is applied more in practice?}

The theory of management has developed two basic principles to ensure the internal consistency of organizations. These principles were identified by Peter Drucker (1998) when considering the nature of organizations. According to Drucker, the organization of type commands and controls is similar to an organism that holds together in its shell. A new form of organization which is appearing today is based on a supporting framework of information. Information is the new integration system of enterprises (it is a necessary precondition for internal cohesion, because responsibility and, thus, self-management cannot exist without shared information) and expression (the ability to acquire information determines the future of the company, because information can be seen as a tool for wealth creation). Traditional management therefore assumes that people must be controlled. The emerging postmodern form of management, by contrast, argues that people must be led. In the economy, information is a new source of wealth; it also means power. Each of these principles, however, shares information within organizations in quite different ways. While traditional management shares only some information, successful leadership is based on the creation of a transparent, open environment in which information becomes the essence of independent and responsible behaviour. Simply put, if companies do not share information, they cannot expect people to manage themselves.

The functioning of complex living systems is characterized by the fact that perception and action always take place on the local scale. The existence of centralized control is therefore possible only due to a complex network of local controls. This regularity corresponds to the principle of subsidiarity, according to which decisionmaking and responsibility within the system should be transmitted to the lowest possible level. In an unstable environment of many variables, the principle of leadership (i.e. to create a vision, to share and communicate the vision, to inspire) appears as an important principle for the strengthening of subsidiarity. The principle of leadership is becoming an alternative to the principle of traditional management, which accumulates too much power in one function (or site), which, in turn, may cause hierarchical breakdown in conditions of uncertainty.

Management (i.e. planning, organization, command and control) is appropriate only when it is applied to nonliving parts of the organization (property and financial capital). Leadership is the key to creating the structure of the engagement which offers the required degree of freedom (and responsibility) in workplaces characterized by synergies in things and relations. The importance of leadership, which increases with increasing complexity and interdependence, is underlined by John Kotter (2000) who sees leadership as a fundamental principle affecting the ability of organizations to adapt to a world of constant change. This research therefore focused on the occurrence of these principles in practice in order to determine whether and to what extent leadership, as one of the principles of the biotic organization, is rooted in the practice of contemporary enterprises (namely in the context of fundamental changes which the external environment has undergone in the last forty years).

The results in Table 10 indicate that leadership is still insufficiently exploited due to the character of the environment in which enterprises exist today. (The characteristic features of the current environment are uncertainty, nonlinearity, and free will.) 
Table 10. The occurrence of management and leadership in practice

\begin{tabular}{c|c|c}
\hline $\begin{array}{c}\text { Which of these principles is applied } \\
\text { more in your organization? }\end{array}$ & Relative in (\%) & p-value (1- $\alpha=0.95)$ \\
\hline Management (control and planning) & 71.42 & 0.765505984 \\
\hline Leadership (sharing vision and inspiration) & 28.57 & 0.412114051 \\
\hline
\end{tabular}

Source: Authors research.

Management, as one of the most important principles of mechanical organizations, is an integral part of the management systems of more than two thirds of the organizations included in this study. The ability to create a shared vision and transform working conditions to encourage inner motivation was observed in less than a third of organizations. It was also discovered that there is not a significant positive relationship between company size and principles of management and leadership, which means that hypothesis $\mathrm{H} 4_{1}$ (there is statistically significant differences between company size and principles of management and leadership) is rejected (see Figure 6).

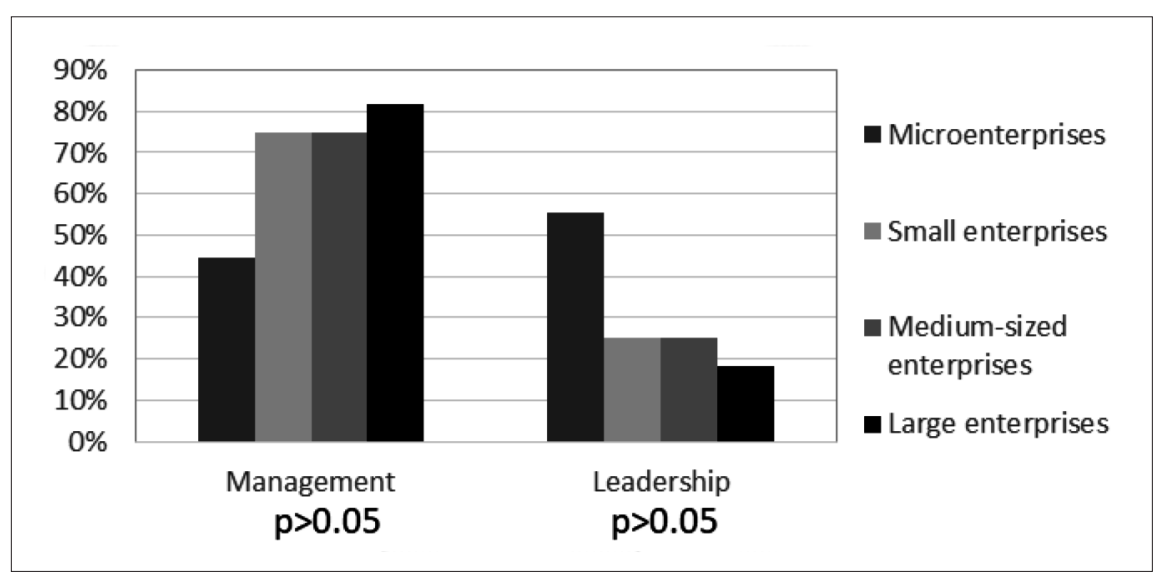

Fig. 6. The principles of management and leadership within the context of company size.

The environment of engagement and freedom occurs especially in small organizational units (no more than ten employees). The backbones of most large organizations are constituted by an authoritarian form of management based on predictability and controllability, which are the basic assumptions of traditional management.

\subsection{Population of biotic organizations}

On the basis of our own earlier research, it was found that the predominant organizational form is a hybrid organization combining mechanistic and biotic elements. The predominance of mechanistic principles in the operational infrastructure of business organizations supports the research assumption that the principles of biotic organization in the practices of current companies are underdeveloped.

The research thus focused on exploring the four areas of the organization which deliberately follow the four dimensions of whole person paradigm as a prototype for creating of biotic organization in order to verify the initial assumption about the occurrence of biotic organizations in the business environment. The previous chapters introduced the results of quantitative and qualitative research, according to which the level of structuring in organizational entities and their abilities to empower, share purposes, evoke a sense of partnership, and define their own purpose of existence were evaluated.

The results of the survey, which were processed by using the Venn diagram, are shown in the following figure (Figure 7). 


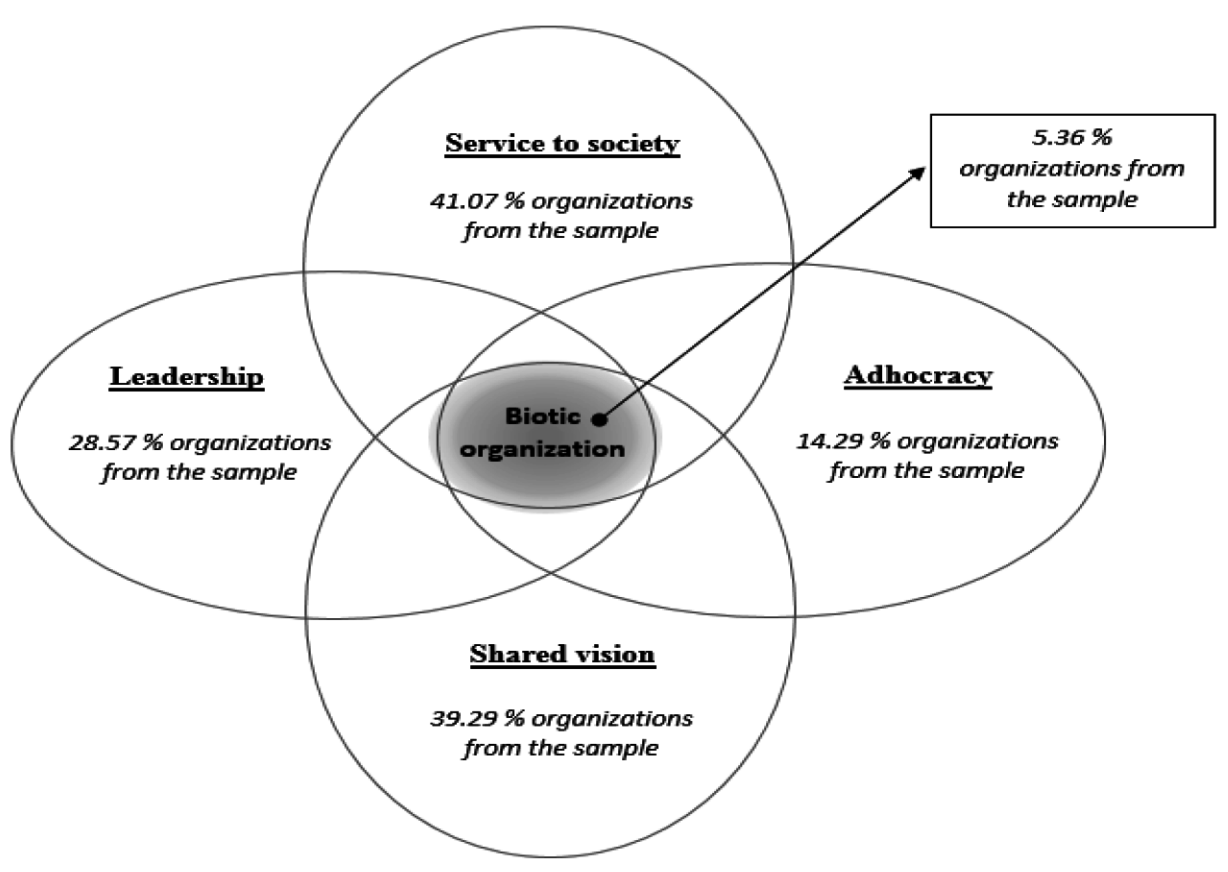

Fig. 7. Occurrence of biotic organizations in the business environment.

Data from this research provided answers to research questions regarding the representation of the principles of biotic organization in practice. Network-organized institutions, whose coherence entails the principle of leadership as a tool for sharing visions and empowering individuals and the principle of a widely shared vision as a discipline creating an environment of shared purpose and partnerships with a purpose that goes beyond just making money, represent only a minority of organizations in the economic environment (approximately $5 \%$ of the total organizational population).

Analysis of the data also showed that the principles of biotic organization are not dependent on organizational size. In this context, it was tested whether there is a positive relationship between company size and the occurrence of biotic organization ( $\mathrm{H}_{0}$ : There is not a significant positive relationship between company size and the occurrence of biotic organization). The results of this research have shown that there were not statistically significant differences between company size and the occurrence of biotic organization, because value of the test criteria was upper than the level of significant of $\alpha=0.05(\mathrm{p}=0.671049034)$.

\section{Conclusion}

The aim of the article was to construct a model of biotic organization and to map the occurrence of biotic organizations in the economic environment. The research conclusion emerged from an effort to answer the question of whether biotic organizations are represented in practice in more than 10 percent of cases. Based on the analysis of theoretical assumptions, we identified the principles of biotic organization. These principles, which are amorphous structure, leadership, shared vision, and service, created the final form of the four-dimensional organizational model. The occurrence of these principles in practice was verified by survey. The processed data revealed a relatively low frequency of these principles in the practice of contemporary organizations.

The hypothesis that, in practice, biotic organizations represent less than ten percent of cases was confirmed. According to the created model, approximately $5 \%$ of organizations may be considered as biotic organizations. Organizations have particular problems with the creation of a network (amorphous) structure and the more frequent application of soft management practices that create space for self-management.

Future research work should therefore be focused on an analysis of the main management techniques taught mainly at economic universities, with an emphasis on promoting support courses relating to change management, the creation of a shared vision, inspiration, and the creation of an internal environment that will build on the principles of 
freedom and confidence. Of special note is the prevalence of traditional methods of organization and structural forms in current organizations, where, as it turns out, there is almost no alternative to the current pyramidal structure. This is probably a result of the fact that very few companies build management systems without formal hierarchies, ones which are based more on leadership than on management and control, and thus there are too few positive exceptions in the economic environment that could inspire other companies with respect to specific management practices. In this area, it is the practice of some companies more than pure theory that offers much interesting material, whether it is the lattice structure in W. L. Gore, the anti-structure in Semco, the inverted pyramid in the Indian software company HCLT, or the specific structure formed on the basis of agreements between colleagues in Morning Star.

These companies should be subjected to deeper research in order to discover the common characteristics of these new organizational forms and to create a real alternative to the dominant management system built on the principles of mechanics, which prevails not only in the theoretical background, but also in the practice of today's companies.

\section{References}

Bateson, G. (1972). Steps To an Ecology of Mind. New York: Ballantine.

Boulding, K. E. (1956). General systems theory-the skeleton of science.Management science, 2(3), 197-208.

Bragdon, J. H. (2009). Capitalism as a Human System: The Value of Relational Equity. Reflections, 10(1).

Burns, T. E., \& Stalker, G. M. (1961). The management of innovation.University of Illinois at Urbana-Champaign's Academy for Entrepreneurial Leadership Historical Research Reference in Entrepreneurship.

Burns, T., \& Stalker, G. (2000). Mechanistic and organic systems of management. Technology, organizations, and innovation: Critical perspectives on business and management, Routledge, London, New York, 24-50.

Carney, B. M., \& Getz, I. (2013). Freedom, Inc.: Free your employees and let them lead your business to higher productivity, profits, and growth. Praha: PeopleComm.

Čirjevskis, A. (2015). Dynamic capabilities in abmidextrous organisation, decision making pattern for sustainable future, Entrepreneurship and Sustainability Issues, vol 3 no 2, pp. 129-136. https://doi.org/10.9770/jesi.2015.3.2(1)

Cochran, G. W. (1977). Sampling Techniques, New York: Wiley.

Collins, J. C., \& Porras, J. (1994). Built to Last: successful habits of visionary companies. New York: Harper-Business.

Covey, R., S. (2010). The 8th Habit: From Effectiveness to Greatness. Praha: Management Press.

Covey, R., S. (2013). The 3rd Alternative: Solving Life's Most Difficult Problems. Praha: Management Press.

De Geus, A. (1997). The living company: habits for survival in a turbulent environment. London: Nicholas Brealey.

Drucker, P. F. (1995). Management in a Time of Great Change. New York: Dutton

Drucker, P. F. (Ed.). (2003). A Functioning Society: Selections from Sixty-five Years of Wrinting on Community, Society, and Polity. Transaction Publishers.

Fayol, H. (1916). General and Industrial Management. London: Pitman.

Forrester, W., J. (1987). Lessons from system dynamics modeling. System Dynamics Review, vol. 3, no. 2, pp. 136-149.

Gouldner, A. W. (1959). Organizational analysis.

Hamel, G. (2011). First, let's fire all the managers. Harvard Business Review, vol. 89, no. 12, pp. 48-60.

Hamel, G. (2013). What Matters Now. Praha: PeopleComm.

Hamel, G., \& Breen, B. (2008). The Future of Management. Praha: Management Press.

Hammer, M. (2002). The Agenda: What Every Business Must Do to Dominate the Decade. Praha: Management Press.

Hammer, M., \& Champy, J. (1993). Reengineering the Corporation. New York: HaperCollins. 
Handy, C. (1989). The age of unreason. London: Century Business.

Handy, C. (1997). Hungry Spirit: Beyond Capitalism: A Quest for Spirit in the Modern World. London: Hutchinson.

Harung, S. H. (2004). Invincible Leadership. Praha: Euromedia Group.

Heskett, J. L., \& Kotter, J. P. (1992). Corporate culture and performance. Business Review. Vol, 2, 83-93.

Hock, D. (2000). Birth of the Chaordic Age. San Francisco: Berrett-Koehler Publishers.

Hock, D. (2005). One from many: Visa and the rise of chaordic organization. San Francisco: Berrett-Koehler Publishers.

Katz, D., \& Kahn, R. L. (1978). The social psychology of organizations.

Kaźmierczyk, J.; Aptacy, M. (2016). The management by objectives in banks: the Polish case, Entrepreneurship and Sustainability Issues, vol 4, no 2, p.p. 146-158. https://doi.org/10.9770/jesi.2016.4.2(3)

Kelly, K. (1995). Out of control: the new biology of machines, social systems and the economic world. Basic Books.

Kelly, K. (2007). The New Biology of Business. In Gibson, R., Rethinking the Future: Rethinking Business Principles Competition Control \& Complexity Leadership Markets and the World. Praha: Management Press.

Kiefer, Ch, \& Stroh, P. (1983). A new paradigm for organization development. Training \& Development Journal, Vol. 37, No. 4, pp. $26-34$.

Kotter, P. J. (2000). Leading Change. Praha: Management Press.

Kotter, P. J., Heskett, L. J. (1992). Corporate Culture and Performance. New York: Free Press.

Lawrence, P. R., Lorsch, J. W., \& Garrison, J. S. (1967). Organization and environment: Managing differentiation and integration (p. 1976). Boston, MA: Division of Research, Graduate School of Business Administration, Harvard University.

Luhmann, N. (1986). The autopoiesis of social systems. Sociocybernetic paradoxes, 172-192.

Prahalad, C. K., \& Ramaswamy, V. (2013). The future of competition: Co-creating unique value with customers. Harvard Business Press.

Sandow, D., \& Allen, A. M. (2005). The nature of social collaboration: how work really gets done. Reflections: The SoL Journal, 6(2-3), 2-3.

Senge, P. (1990). The fifth discipline: The art and practice of the learning organization. New York: Currency Doubleday.

Senge, P. (2007). Through the Eye of a Needle. In Gibson, R., Rethinking the Future: Rethinking Business Principles Competition Control \& Complexity Leadership Markets and the World. Praha: Management Press.

Senge, P., \& Carstedt, G. (2001). Inovating Our Way to the Next Industrial Revolution. Sloan Management Review, vol. 42, pp. $24-38$. Slinták, K. (2013). The Principles of Mechanical Organization. Auspicia, vol. 10, no. 2, pp. 28-34.

Taylor, W. F. (1911). The principles of scientific management. New York \& London: Harper Brothers.

Thompson, J. D. (1967). Organizations in action. 1967. SHAFRITZ, Jay M.; OTT, J. Steven. Classics of organization theory, 4.

Thompson, J. D. (2011). Organizations in action: Social science bases of administrative theory (Vol. 1). Transaction publishers.

Thompson, J. D., \& Hawkes, R. W. (1962). Disaster, community organization and administrative process. Administrative Science Center, University of Pittsburgh.

Tvaronavičienė, M. (2016). Start-ups across the EU: if particular tendencies could be trace, Entrepreneurship and Sustainability Issues, vo. 3, no 3, pp. 290-298. https://doi.org/10.9770/jesi.2016.3.3(6)

Weber, M. (1947). The theory of economic and social organization. Trans. AM Henderson and Talcott Parsons. New York: Oxford University Press.

Karel SLINTÁK - PhD, Tomas Bata University in Zlín, Czech Republic) is an academic and a researcher at the Faculty of Management and Economics. His research interests include management innovation, system theory and information system of organizations influencing their adaptability. Currently, he deals with trends in systems of management and examines selected firms aplying some elements of self-management. He is a member of a research project supported by Faculty of Management and Economics focused on social aspects of entrepreneurship. 